\title{
Coal Resources of Selected Coal Beds and Zones in the Northern and Central Appalachian Basin
}

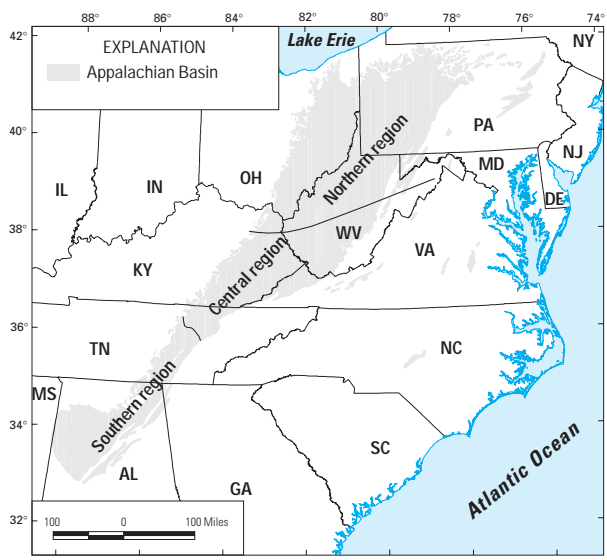

Figure 1. Locations of the three Appalachian Basin coal regions. Assessments were conducted on selected coal beds and zones in the northern and central coal regions, where 95 percent of Appalachian bituminous coal is produced. The Appalachian Basin is one of five regions being assessed in the U.S. Geological Survey's N ational Coal Resource Assessment.

The Appalachian Basin is one of the most important coal-producing regions in the world (figs. 1-3, table 1). Bituminous coal has been mined in the basin for the last three centuries, and the cumulative production is estimated at 34.5 billion short tons. Annual production in 1998 was about 452 million

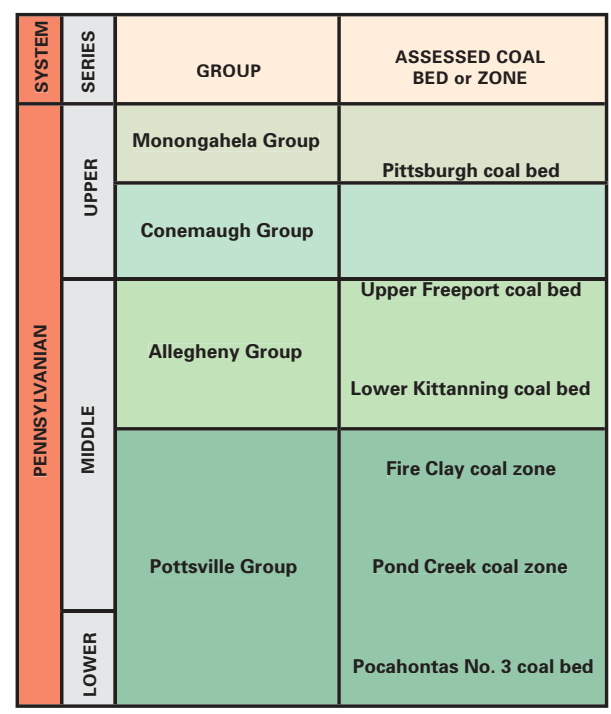

Figure 2. Generalized stratigraphic column showing the relative positions of the five assessed coal beds and zones (plus the Lower Kittanning coal bed) in the northern and central Appalachian Basin coal regions.

short tons (Energy Information Administration, 1999); the basin's production is mostly in the northern (32 percent) and central (63 percent) coal regions. The coal is used primarily within the Eastern United States for electric power generation, but some of it is suitable for metallurgical uses.

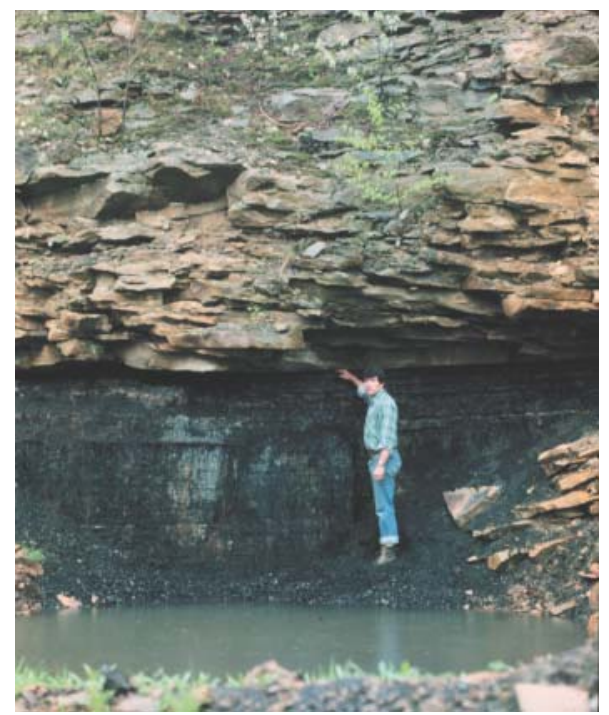

Figure 3. Contact between the Upper Freeport coal bed and the overlying sandstone in Pennsylvania. Photograph courtesy of J ames Shaulis, Pennsylvania Bureau of Topographic and Geologic Survey.

The U.S. Geological Survey (USGS) is completing a National Coal Resource Assessment of five coal-producing regions of the United States, including the Appalachian Basin. The USGS, in cooperation with the State geological surveys of Kentucky (KY), Maryland (MD), Ohio (OH), Pennsylvania (PA),

Table 1. Original (Orig.) and remaining (Remain) coal resources (in millions of short tons) by State in each of five assessed coal beds or zones in the northern and central A ppalachian Basin coal regions.

[Resource estimates are rounded to two significant figures. Asterisk $(*)$ indicates that resources are less than reported here because mine maps are not current. Data are from Northern and Central Appalachian Basin Coal Regions Assessment Team, in press]

\begin{tabular}{|c|c|c|c|c|c|c|c|c|c|c|c|c|c|c|}
\hline \multirow{2}{*}{$\begin{array}{l}\text { Coal bed } \\
\text { or zone }\end{array}$} & \multicolumn{2}{|c|}{ PA } & \multicolumn{2}{|c|}{$\mathrm{OH}$} & \multicolumn{2}{|c|}{$\mathrm{MD}$} & \multicolumn{2}{|c|}{ WV } & \multicolumn{2}{|c|}{ KY } & \multicolumn{2}{|c|}{ VA } & \multicolumn{2}{|c|}{ Total } \\
\hline & Orig. & Remain & Orig. & Remain & Orig. & Remain & Orig. & Remain & Orig. & Remain & Orig. & Remain & Orig. & Remain \\
\hline Pittsburgh & 15,000 & 5,000 & 5,900 & 3,200 & 261 & 0 & 13,000 & 7,800 & -- & -- & - - & - - & 34,000 & 16,000 \\
\hline Upper Freeport & 16,000 & 14,000 & 12,000 & 12,000 & 910 & $<810^{*}$ & 5,000 & 4,500 & -- & -- & -- & -- & 34,000 & $<31,000^{*}$ \\
\hline Fire Clay & -- & -- & -- & -- & -- & - - & 2,100 & 1,800 & 4,200 & 3,200 & 55 & 49 & 6,300 & 5,100 \\
\hline Pond Creek & -- & -- & -- & -- & -- & -- & 5,600 & 5,000 & 4,600 & 3,300 & 570 & 370 & 11,000 & 8,700 \\
\hline Pocahontas No. 3 & -- & -- & -- & -- & -- & -- & 4,300 & 2,600 & -- & -- & 2,900 & 2,500 & 7,200 & 5,100 \\
\hline Total & $\overline{31,000}$ & $\overline{19,000}$ & $\overline{18,000}$ & $\overline{15,000}$ & $\overline{1,200}$ & $\overline{<810}^{*}$ & $\overline{30,000}$ & $\overline{22,000}$ & $\overline{8,800}$ & $\overline{6,500}$ & $\overline{3,500}$ & $\overline{2,900}$ & $\overline{93,000}$ & $<\overline{66,000} *$ \\
\hline
\end{tabular}



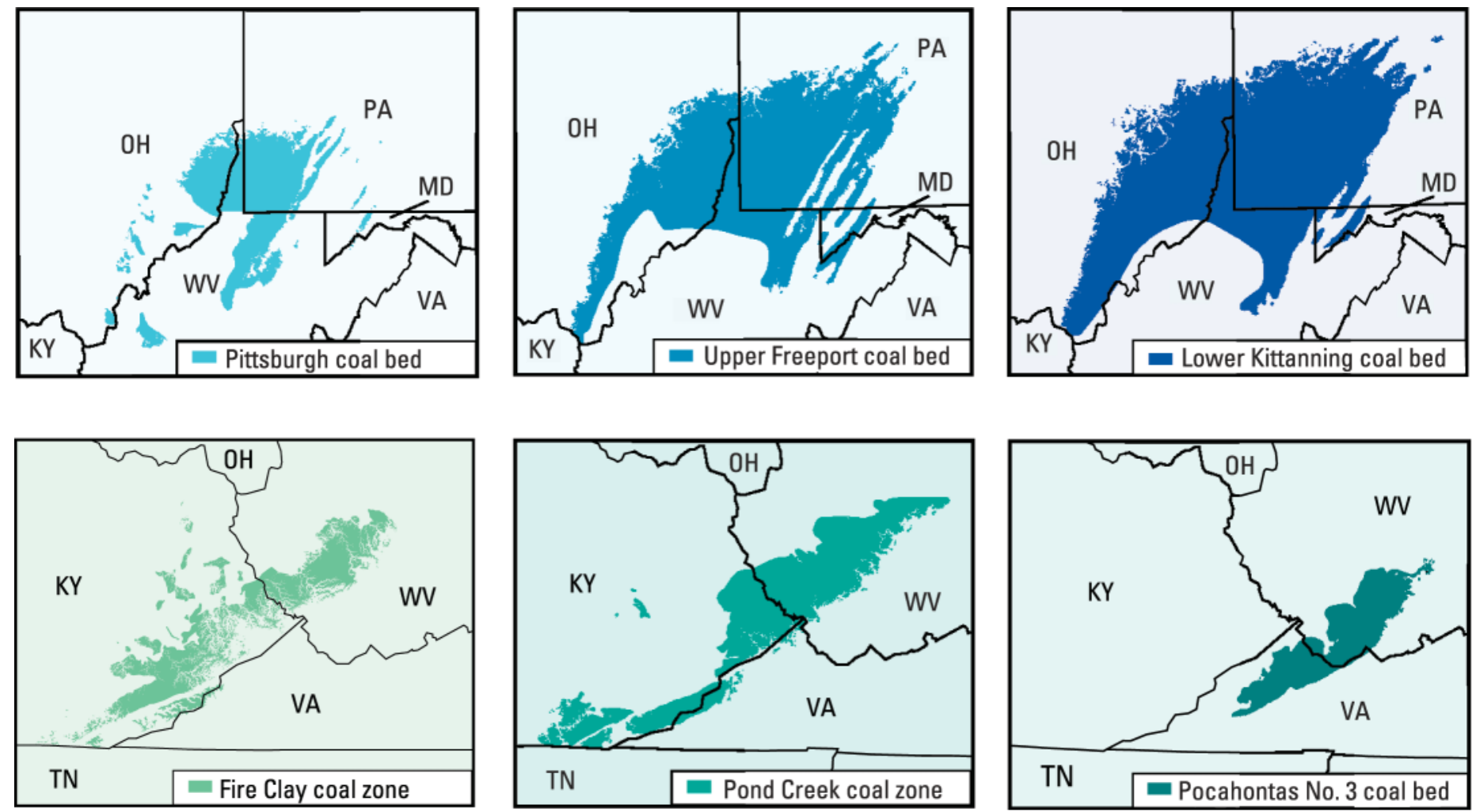

Figure 4. M aps of the northern and central Appalachian Basin coal regions showing the distribution of know $n$ coal resources in the Low er Kittanning coal bed and the five assessed coal units: Pittsburgh coal bed, Upper Freeport coal bed, Fire Clay coal zone, Pond Creek coal zone, and Pocahontas No. 3 coal bed.

Virginia (VA), and West Virginia (WV), has completed a digital coal resource assessment of five of the top-producing coal beds and coal zones in the northern and central Appalachian Basin coal regions (fig. 2). These are the Pittsburgh coal bed, the Upper Freeport coal bed, the Fire Clay and Pond Creek coal zones, and the Pocahontas No. 3 coal bed. Of the 93 billion short tons of original coal in these units, about 66 billion short tons remain (table 1). Results and data are being released in USGS Professional Paper 1625-C (Northern and Central Appalachian Basin Coal Regions Assessment Team, in press).

\section{ASSESSMENT METHODOLOGY}

More than 1,000 previously published and unpublished maps were digitized and combined in a geographic information system (GIS) to create databases that describe the areal extent and mined areas of each of the five assessed coal beds and coal zones. Comprehensive stratigraphic and geochemical databases were built and used to make coverages showing coal thickness, elevation, overburden thickness, and geochemical data. Coverages were combined to calculate original and remaining coal resources.
In addition, areal extent, mined areas, and geochemical coverages were compiled for a sixth coal bed, the Lower Kittanning coal bed in the northern Appalachian Basin coal region (fig. 4). Resources were not calculated for the Lower Kittanning because the stratigraphic databases were incomplete.

Ash yield, sulfur content, calculated sulfur dioxide content, and gross calorific value are summarized in table 2 for the five assessed coal beds and zones and the Lower Kittanning coal bed. For each assessed coal unit, 12 additional chemical parameters (antimony, beryllium, cadmium, chlorine, chromium, cobalt, lead, manganese, nickel, selenium, arsenic, and mercury) were mapped and were included in USGS Professional Paper 1625-C.

Sulfur dioxide $\left(\mathrm{SO}_{2}\right)$ contents were calculated to estimate potential $\mathrm{SO}_{2}$ emissions. Phase II of the Clean Air Act Amendments of 1990 (Public Law 101-549) was implemented in January 2000 and capped powerplant $\mathrm{SO}_{2}$ emissions nationally. This cap limits a plant's emissions to 1.2 pounds of $\mathrm{SO}_{2}$ emitted per million British thermal units (lbs $\mathrm{SO}_{2} /$ million Btu). Some calculated $\mathrm{SO}_{2}$ values in table 2 exceed the cap, but the coal can still be utilized if it is blended with low-sulfur coal, washed to remove sulfur, or combusted in powerplants that have installed flue-gas-desulfurization units.

\section{RESULTS OF THE DIGITAL ASSESSMENTS}

\section{Pittsburgh Coal Bed (Northern Appalachian Basin Coal Region)}

The Pittsburgh coal bed extends for more than 5,000 square miles $\left(\mathrm{mi}^{2}\right)$ in Pennsylvania, Ohio, Maryland, and West Virginia (fig. 4). The Pittsburgh coal is high in calorific value (table 2) and is used primarily for electric power generation. In over 220 years, the Pittsburgh coal bed has produced more coal than any other U.S. coal bed. Currently, it is the top producer in the Appalachian Basin and the second largest in the Nation (Energy Information Administration, 1999). Overall, the Pittsburgh is a medium-ash and medium-sulfur coal bed (table 2). Calculated $\mathrm{SO}_{2}$ values for the coal (table 2) do not meet current emission standards (1.2 lbs $\mathrm{SO}_{2} /$ million $\mathrm{Btu}$ ), but usage continues because the 
Table 2. Arithmetic means of ash yield, sulfur content, calculated sulfur dioxide content, and gross calorific value for the Lower Kittanning coal bed and the five assessed coal units in the northern and central Appalachian Basin coal regions.

[Data are from USGS Professional Paper 1625-C (Northern and Central Appalachian Basin Coal Regions Assessment Team, in press). wt \%, arb = weight percent, as-received whole-coal basis; $1 \mathrm{bs} \mathrm{SO}_{2} /$ million $\mathrm{Btu}=$ pounds of sulfur dioxide per million British thermal units]

\begin{tabular}{lcccc}
\hline Coal bed or zone & $\begin{array}{c}\text { Ash yield } \\
(\text { wt \%, arb })\end{array}$ & $\begin{array}{c}\text { Sulfur content } \\
(\text { wt \%, arb })\end{array}$ & $\begin{array}{c}\mathrm{SO}_{2} \text { content } \\
\left(\mathrm{lbs} \mathrm{SO}_{2} / \text { million Btu }\right)\end{array}$ & $\begin{array}{c}\text { Gross calorific value } \\
(\mathrm{Btu} / \mathrm{lb})\end{array}$ \\
\hline Pittsburgh & 9.02 & 2.80 & 4.34 & 13,130 \\
Upper Freeport & 12.31 & 2.24 & 3.46 & 12,950 \\
Lower Kittanning & 11.98 & 2.90 & 4.40 & 12,890 \\
Fire Clay & 10.62 & .99 & 1.55 & 12,910 \\
Pond Creek & 7.24 & 1.05 & 1.57 & 13,540 \\
Pocahontas No. 3 & 5.75 & .66 & .91 & 14,490 \\
\hline
\end{tabular}

coal is thick, conducive to longwall mining, and high in gross calorific value. Original resources of the Pittsburgh coal bed are estimated at 34 billion short tons (bst), and about 16 bst remain (table 1). Extensive blocks of thick (6-8 feet), minable coal occur in southwestern Pennsylvania and the northern panhandle of West Virginia. Much of the remaining Pittsburgh resource outside of these blocks is high in ash yield and sulfur content and is not likely to be extensively mined in the near future.

\section{Upper Freeport Coal Bed (Northern Appalachian Basin Coal Region)}

The Upper Freeport coal bed occupies more than $14,000 \mathrm{mi}^{2}$ in Pennsylvania, Ohio, Maryland, and West Virginia (figs. 3-5). Although production is declining, the Upper Freeport remains the third most productive coal bed in this region and the 14th largest producer in the United States (Energy Information Administration, 1999). Overall, the Upper Freeport coal bed is classified as a medium-ash, medium-sulfur, and high-calorific-value coal (table 2), but it fails to meet current $\mathrm{SO}_{2}$ emission standards without blending or scrubbing. Original total resources of the Upper Freeport coal bed are estimated at 34 bst, of which less than 31 bst remain (table 1). Pods of thick coal remain under deep overburden (>1,000-2,000 feet) and are unlikely to be mined. Relatively shallow resources remain in Pennsylvania and Ohio; they can be mined and combusted in powerplants that blend coal or are equipped with flue-gasdesulfurization units.

\section{Fire Clay Coal Zone (Central Appalachian Basin Coal Region)}

The Fire Clay coal zone is called the Hazard No. 4 coal bed in Kentucky and the Phillips coal bed in Virginia. Unlike the Pittsburgh, Upper Freeport, and Pocahontas No. 3 coal beds, the Fire Clay is a zone comprising multiple benches of coal and associated rock that are of variable thickness and extent. Coal benches that are most likely to be mined were used to estimate resources. The Fire Clay coal zone is distributed throughout approximately $5,500 \mathrm{mi}^{2}$ in West Virginia, Kentucky, and Virginia (fig. 4). The coal is mined predominantly from underground mines and is used for electric power generation. The Fire Clay coal is a high-calorific-value, mediumash, low-sulfur coal that is blended with other low-sulfur coals to meet current $\mathrm{SO}_{2}$ emission standards (table 2). Resource estimates show that 5.1 bst remain of the original $6.3 \mathrm{bst}$ (table 1); most of the remaining resource is in Leslie and Knott Counties, KY, and Boone County, WV. The Fire Clay is expected to continue as a major producer in the central Appalachian Basin coal region for the next decade.

\section{Pond Creek Coal Zone (Central Appalachian Basin Coal Region)}

The Pond Creek coal zone is called the Lower Elkhorn coal bed in Kentucky, the Imboden coal bed in Virginia, and the Eagle coal zone in West Virginia. The Pond Creek coal zone extends for $8,700 \mathrm{mi}^{2}$ (fig. 4), of which almost $3,700 \mathrm{mi}^{2}$ were assessed. Coal beds of the Pond
Creek coal zone are mined extensively underground and at the surface; the coal is used mainly for electric power generation. Although less extensive and generally thinner than other top-producing Appalachian coal beds, the Pond Creek coal is highly desirable because of its relatively low ash yield and sulfur content and high calorific value (table 2). Much of the Pond Creek coal must be blended or physically cleaned to meet current $\mathrm{SO}_{2}$ emission standards. Resource estimates for the Pond Creek coal zone were calculated on individual coal benches or deposits that are most likely to be mined. Of the calculated original resource of 11 bst, about 8.7 bst remain (table 1). West Virginia has the largest remaining resource of Pond Creek coal where the coal is relatively thick and shallow.

\section{Pocahontas No. 3 Coal Bed (Central Appalachian Basin Coal Region)}

The Pocahontas No. 3 coal bed is present in southern West Virginia and southwestern Virginia (fig. 4) and has produced more high-quality coal than any other coal bed in Virginia. It continues to yield coal, and in some areas, it is being exploited for its coal-bed methane resources. The Pocahontas No. 3 coal bed is low in ash and sulfur, is very high in calorific value, and meets current $\mathrm{SO}_{2}$ emission standards (table 2). Resource estimates indicate that the original resources were 7.2 bst of Pocahontas No. 3 coal, of which 5.1 bst remain (table 1). Relatively thick unmined coal remains at depths of $>500-2,000$ feet. 


\section{CONCLUSIONS}

The five assessed units produce over 12 percent of the Nation's coal (Energy Information Administration, 1999). Total original resources are estimated at about 93 bst, of which about 66 bst remain. Much of the remaining coal in these coal beds and zones is thinner and deeper than the coal that has been mined, but economic resources are still available, and mining in each coal unit is anticipated to continue throughout this decade.

Sufficient coal resources remain in the Appalachian Basin to meet regional electrical generation needs. $\mathrm{SO}_{2}$ emission regulations currently favor production of the lower sulfur central Appalachian coals over the more plentiful, but higher sulfur, northern Appalachian coals. Economic pressures may encourage utilities to build new coal-fired powerplants equipped with flue-gas-desulfurization units or to retrofit older units.

This scenario could result in increased demand for northern Appalachian coals.

-Leslie Ruppert, Susan Tewalt, and Linda Bragg

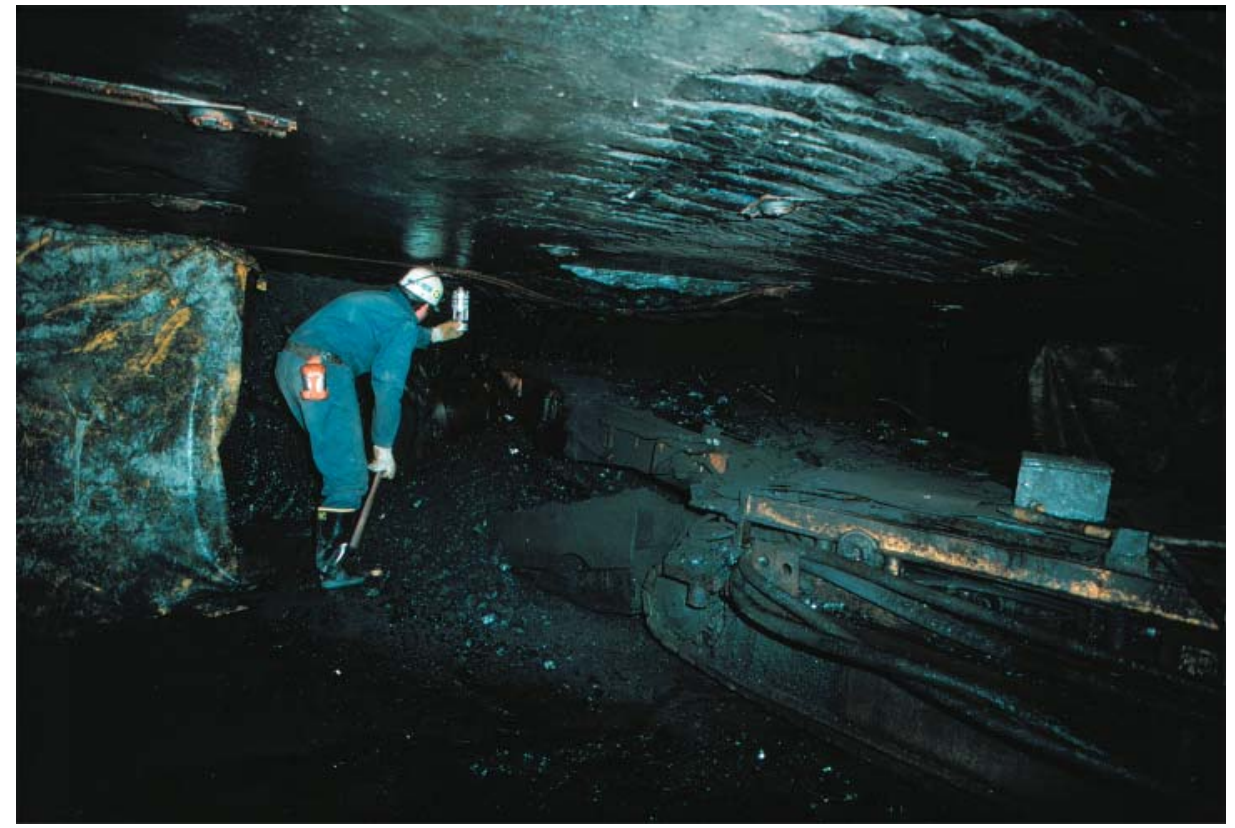

Figure 5. A continuous mining machine in an Upper Freeport coal mine in the Homer City region, Indiana County, PA. Photograph by Ronald Stanton, U.S. Geological Survey.

\section{REFERENCES}

Energy Information Administration, 1999, Production tables [for U.S. coal]_Annual: available online at http://www.eia.doe.gov/cneaf/ $\mathrm{coal} / \mathrm{cia} / \mathrm{html} / \mathrm{aproduct} . \mathrm{html}$. (Accessed Dec. 11, 2001.)

Northern and Central Appalachian Basin Coal Regions Assessment Team, in press, 2000 Resource assessment of selected coal beds and zones in the northern and central Appalachian Basin coal regions: U.S. Geological Survey Professional Paper 1625-C, CD-ROM's.
For more information, please contact:

Leslie F. Ruppert

U.S. Geological Survey

National Center, Mail Stop 956

Reston, VA 20192

Telephone: 703-648-6431

E-mail: 1ruppert@usgs.gov 